\title{
J.M. Guerra-García
}

\section{Redescription of five rare caprellids (Crustacea: Amphipoda: Caprellidea) collected from Tanzanian coasts}

Received: 5 December 2000 / Received in revised form: 27 July 2001 / Accepted: 6 August 2001 / Published online: 24 October 2001 (C) Springer-Verlag and AWI 2001

\begin{abstract}
Five species of the Caprellidea from Tanzania are redescribed and illustrated in detail. Falotritella biscaynensis McCain, 1968 and Paracaprella tenuis Mayer, 1903 had previously been reported only from the northwest Atlantic coast; the present work extends their distribution to the Indian Ocean. This study represents the first report on Triprotella amica Arimoto, 1970 since the original description from the Arabian Sea. Protella similis Mayer, 1903 had been found only in Indonesia, Thailand and Philippines prior to this study. Pseudocaprellina pambanensis Sundara Raj, 1927, previously only known from India, is also redescribed.
\end{abstract}

Keywords Caprellidea · New records · Redescriptions · Tanzania

\section{Introduction}

The "Grigore Antipa" National Museum of Natural History of Bucharest organised a scientific expedition to the coast of Tanzania during December 1973 and January 1974. During a visit to the Museum in May 2000 the author studied the collection of the Caprellidea from Tanzania. The complete list of all identified taxa is given by Guerra-García (2001). A consultation of the literature showed that five species had been reported only rarely and a complete description was lacking for most of them. In the present paper, illustrations and detailed descriptions are given for these five species. All the specimens are deposited in the collections of "Grigore Antipa" National Museum of Natural History, Bucharest, Romania.

Communicated by R.M. Kristensen

J.M. Guerra-García (৫)

Laboratorio de Biología Marina,

Departamento de Fisiología y Biología Animal,

Facultad de Biología, Universidad de Sevilla,

Apdo. 1095, 41080 Sevilla, Spain

e-mail: jmguerra@ cica.es

\section{Family Phtisicidae Vassilenko, 1968}

Genus Pseudocaprellina Sundara Raj, 1927

Pseudocaprellina pambanensis Sundara Raj, 1927

Sundara Raj (1927) (Figs. 1, 2, 3, 4).

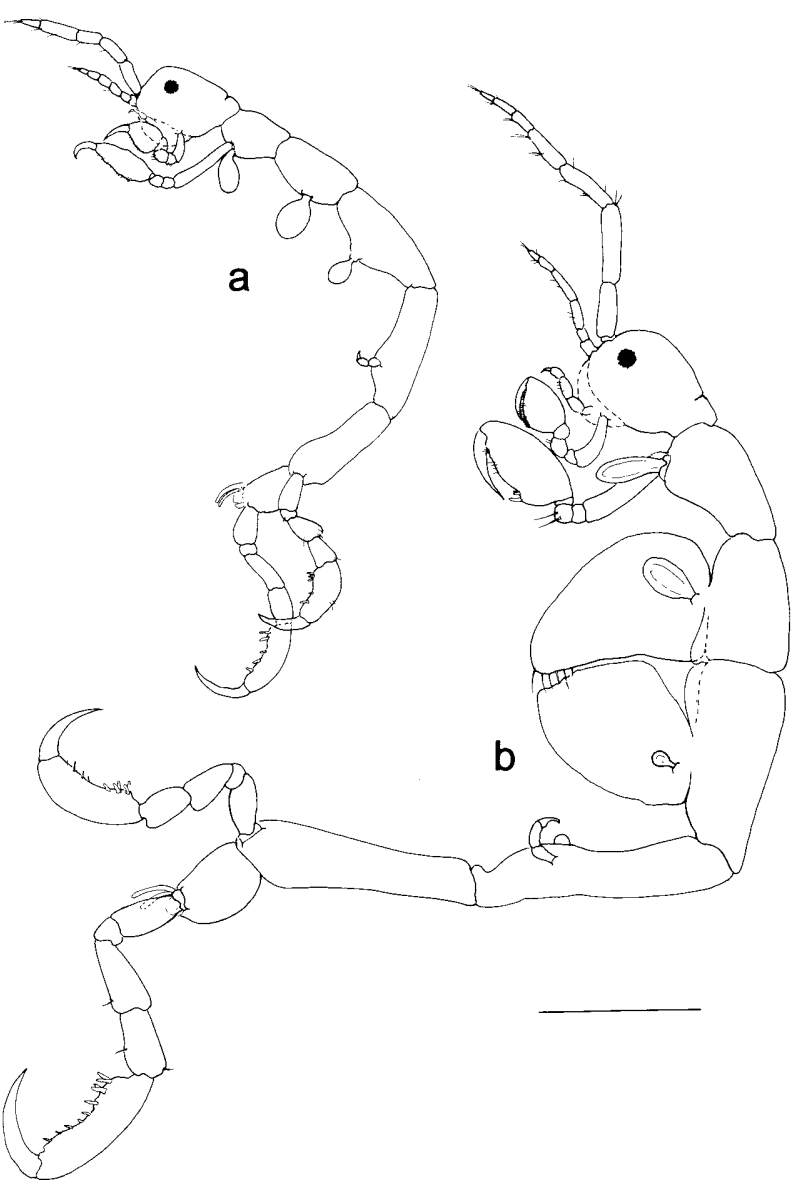

Fig. 1a, b Pseudocaprellina pambanensis Sundara Raj, 1927. Lateral view. a Juvenile, b female. Scale bar $0.5 \mathrm{~mm}$ 


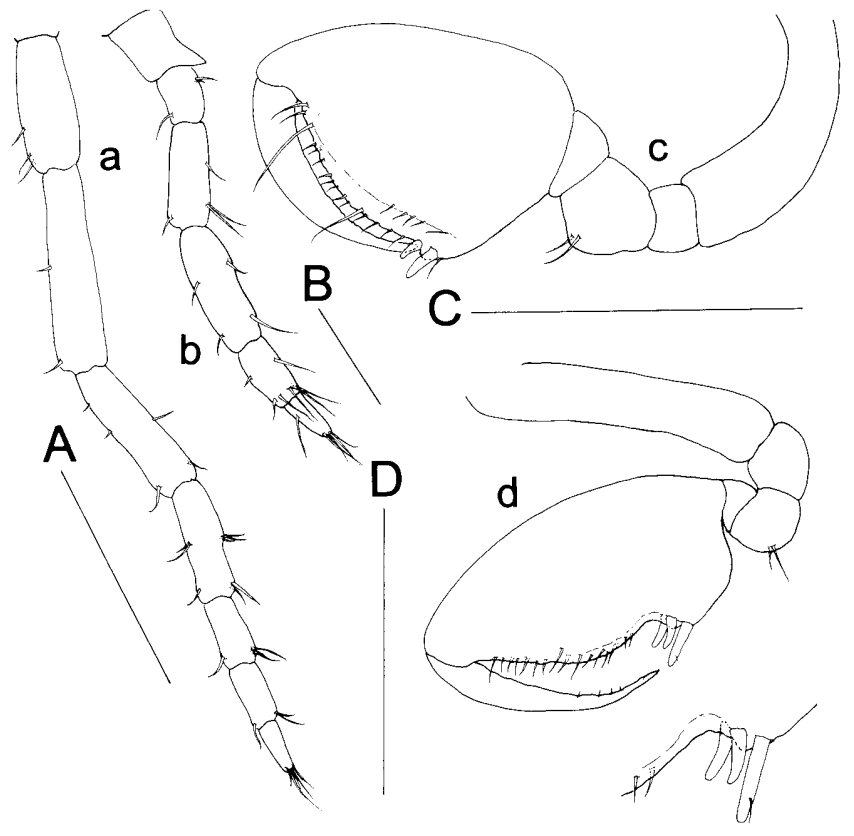

Fig. 2a-d Pseudocaprellina pambanensis Sundara Raj, 1927. Female: a antenna 1, b antenna 2, c gnathopod 1, d gnathopod 2. Scale bars, A $0.3 \mathrm{~mm}$ (a), B $0.1 \mathrm{~mm}$ (b), C $0.2 \mathrm{~mm}(\mathbf{c}), D 0.3 \mathrm{~mm}$ (d)

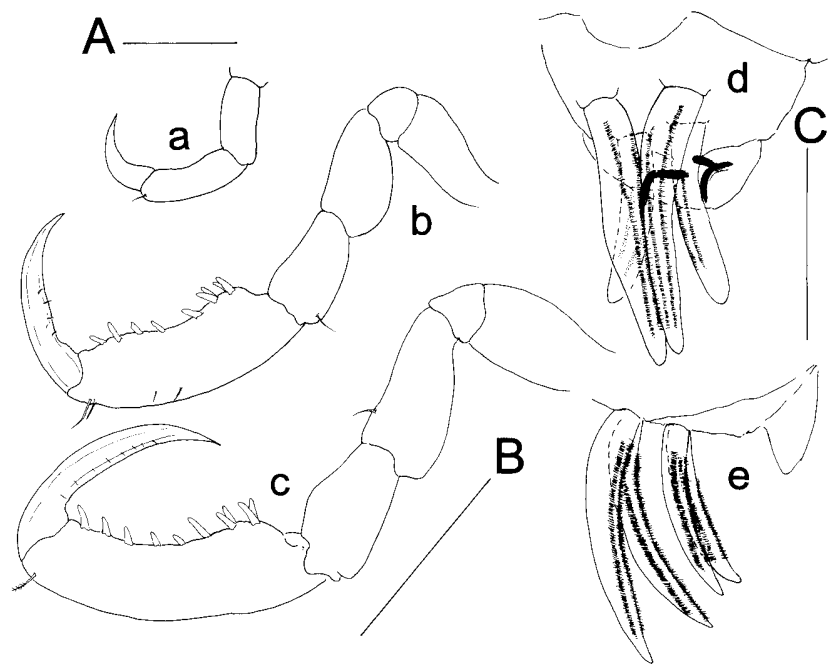

Fig. 3a-e Pseudocaprellina pambanensis Sundara Raj, 1927. Female: a pereopod 5, b pereopod 6, c pereopod 7, $\mathbf{d}$ abdomen, ventral view, e abdomen, lateral view. Scale bars, A $0.2 \mathrm{~mm}$ (a), $B 0.3 \mathrm{~mm}(\mathbf{b}, \mathbf{c}), C 0.1 \mathrm{~mm}(\mathbf{d}, \mathbf{e})$

Pseudocaprellina pambanensis Sundara Raj, 1927

Sundara Raj (1927: p. 127, pl. 17); Sivaprakasam (1977: pp. 80-82, Figs.1 and 2).

\section{Material examined}

One female, one juvenile from Bahary Beach, collected at low tide, 25 December 1973.

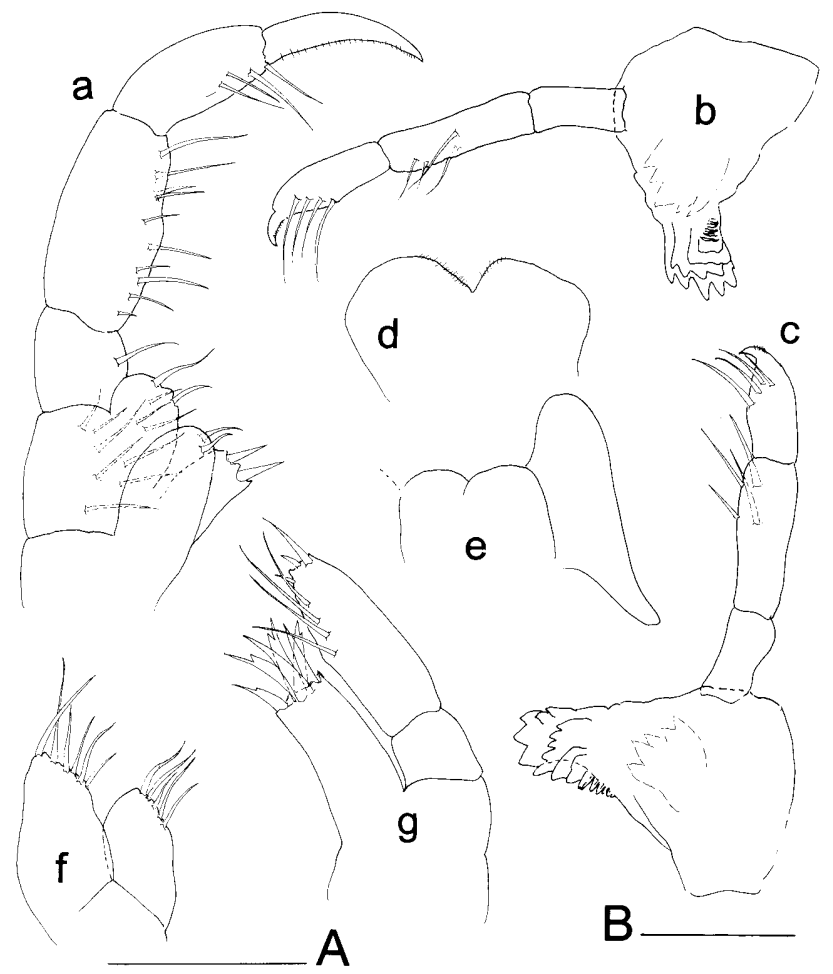

Fig. 4a-g Pseudocaprellina pambanensis Sundara Raj, 1927. Female: a maxilliped, b right mandible, $\mathbf{c}$ left mandible, $\mathbf{d}$ upper lip, e lower lip, $\mathbf{f}$ maxilla 2, $\mathbf{g}$ maxilla 1 . Scale bars $0.05 \mathrm{~mm}$. A (f, g), $B(\mathbf{a}-\mathbf{d})$

\section{Description}

Mature female. Body length $7.1 \mathrm{~mm}$. Body smooth without dorsal projections. Suture between head and pereonite present. Cephalon (head plus pereonite 1), pereonites 2 and 3 subequal in length. Gills on pereonites 2-4; first pair elongate, length ca. 2.7 times width; the second pair wider, length ca. 1.8 times width; the third pair rounded ca. 1/4 as large as the second pair.

Antenna 1 ca. 4 times shorter than the body; article 2 of the peduncle the longest; flagellum 4-articulate.

Antenna 2 as long as the peduncular articles 1 and 2 of the antenna 1; swimming setae absent; peduncular article 1 with an acute projection distally; flagellum 2-articulate.

Gnathopod 1 basis ca. 1.5 times longer than ischium to carpus combined; propodus oval, length ca. 1.3 times width; palm convex, with 2 grasping spines; dactylus smooth.

Gnathopod 2 inserted in the anterior half of pereonite 2 ; basis nearly as long as pereonite 2 ; propodus elongate, length ca. 2.2 times width; palm convex with 3 grasping spines proximally.

Pereopod 5 reduced to 3 articles, nearly 4 times shorter than pereonite 5 .

Pereopods 6 and 7 similar in morphology but decreasing in length; propodus palm carrying 2 pairs of grasping spines and a row of 5 or 6 single ones along the palm. 
Abdomen with 2 pairs of uni-articulate appendages and a dorsal lobe.

Mouthparts: Upper lip symmetrically bilobed, scarcely setose apically. Lower lip inner lobes not very well marked; outer lobe with a slender proximal projection. Maxilliped inner plate divided into 2 lobes, the inner rectangular, provided with 2 distal spines, and the outer rounded with 2 apical setae. Mandibles with palp; molar process lacking. Incisor and lacinia mobilis 5-toothed followed by a row of plates decreasing in size; palp with 3 articles, article 1 without setae, article 2 carrying 4 setae, article 3 with a setal formula 1-2-1. Maxilla 1 outer lobe with stout apical teeth; distal segment of palp with 2 apical spines and 5 setae medially. Maxilla 2 outer lobe carrying 6 setae; inner lobe, a little shorter than outer lobe, with 5 setae distally.

Habitat

From algae on coral heads.

Distribution

Type locality

Gulf of Mannar, India.

New record

Tanzanian coasts.

Remarks

This species was described by Sundara Raj (1927) based on a male from the Gulf of Mannar, India. After this, Sivaprakasam (1977) described a mature female also from the Gulf of Mannar. The only differences between the female from Tanzania and the female from India is the presence of 3 grasping spines in the propodus palm of gnathopod 2 instead of 2 in the female from India, and the incisor and lacinia mobilis being 5-toothed. In females from India the incisor is 6-toothed and the lacinia mobilis 3-toothed. Nevertheless, taking into account the scarcity of the material examined, this is probably mere intraspecific variation.

\section{Family Caprellidae White, 1847}

Genus Falotritella McCain, 1968

Falotritella biscaynensis McCain, 1968

McCain (1968) (Figs. 5, 6, 7, 8).

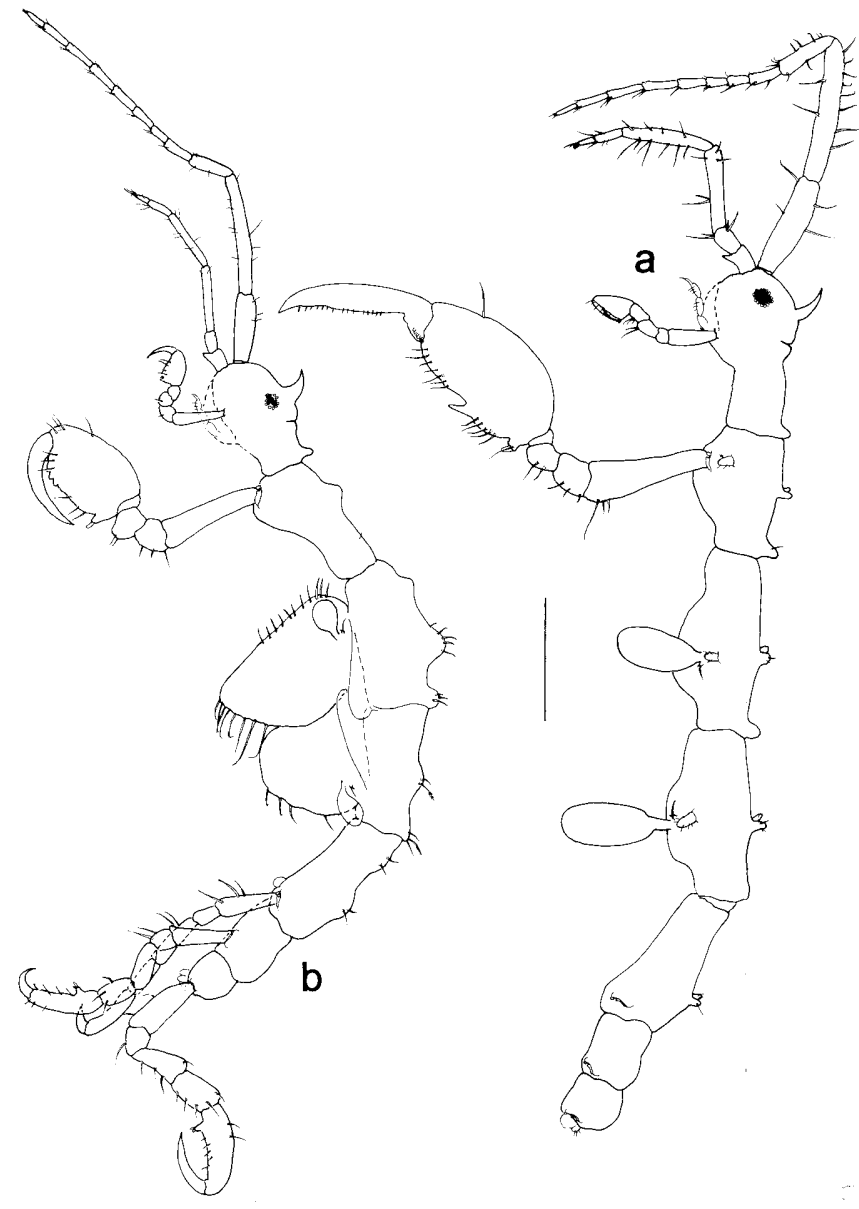

Fig. 5a, b Falotritella biscaynensis McCain, 1968. Lateral view. a male, b female. Scale bar $0.05 \mathrm{~mm}$

Falotritella bicaynensis McCain, 1968

McCain (1968: pp.57-61, Figs.27 and 28); McCain and Steinberg (1970: p. 51); Gable and Lazo-Wasem (1987: pp. 637-638).

\section{Material examined}

One male, two females, one juvenile from Syringodium, 1 December 1973; one female from Mbudya, east of island, collected at low tide, $0.5 \mathrm{~m}$, between corals among Cymodocea, 12 December 1973; one male, two females and one juvenile from Kunduchi, 12 December 1973; one male collected by dredging, $22 \mathrm{~m}$ in depth, 8 January 1974; one male and one female from Mbudya, between corals, 24 January 1974.

\section{Description}

Mature male. Body length $7.3 \mathrm{~mm}$. Head with a single dorsal anteriorly directed acute projection. Pereonite 1 with single postero-dorsal projection; pereonites 2-4 


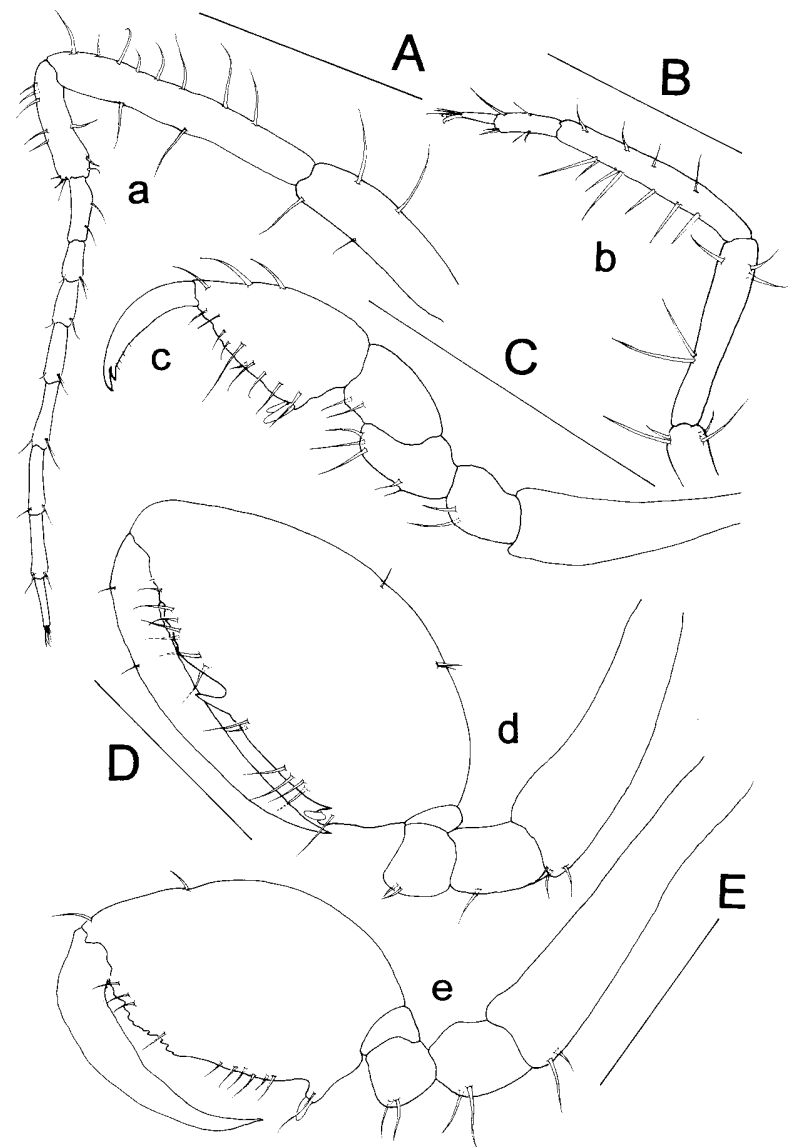

Fig. 6a-e Falotritella biscaynensis McCain, 1968. a-d Male. a antenna 1, b antenna 2, c gnathopod 1, d gnathopod 2. e Female gnathopod 2. Scale bars, A $0.5 \mathrm{~mm}(\mathbf{a}), B 0.2 \mathrm{~mm}$ (b), C: $0.3 \mathrm{~mm}$ (c), $D 0.3 \mathrm{~mm}(\mathbf{d}), E 0.3 \mathrm{~mm}(\mathbf{e})$

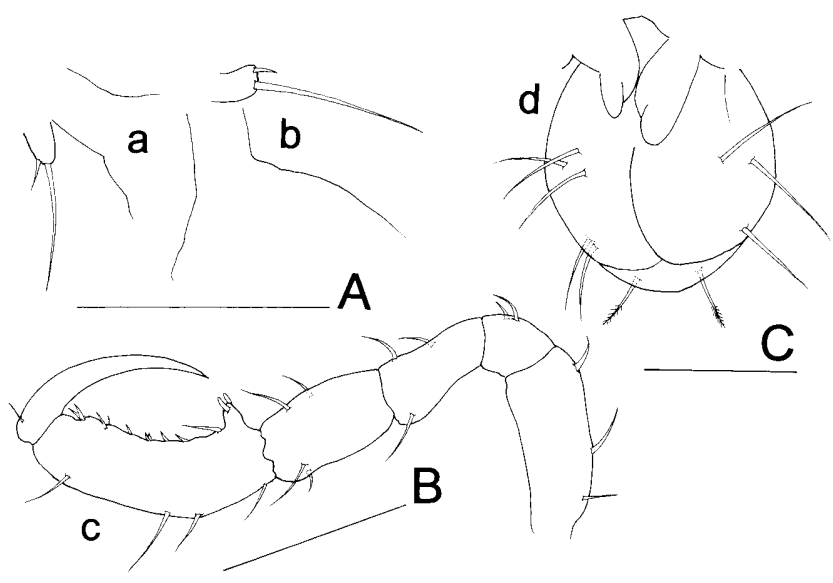

Fig. 7a-d Falotritella biscaynensis McCain, 1968. a, b, d male. a pereopod 3 , b pereopod 4 , d abdomen. c female pereopod 7 . Scale bars, $A 0.1 \mathrm{~mm}(\mathbf{a}, \mathbf{b}), B 0.3 \mathrm{~mm}(\mathbf{c}), C: 0.2 \mathrm{~mm}(\mathbf{d})$

with a pair of dorsal round projections at midlength, a single posterodorsal projection and a pair of lateral tubercles, one in each side; pereonite 5 with a pair of dorsal projections medially; pereonites 6 and 7 smooth.

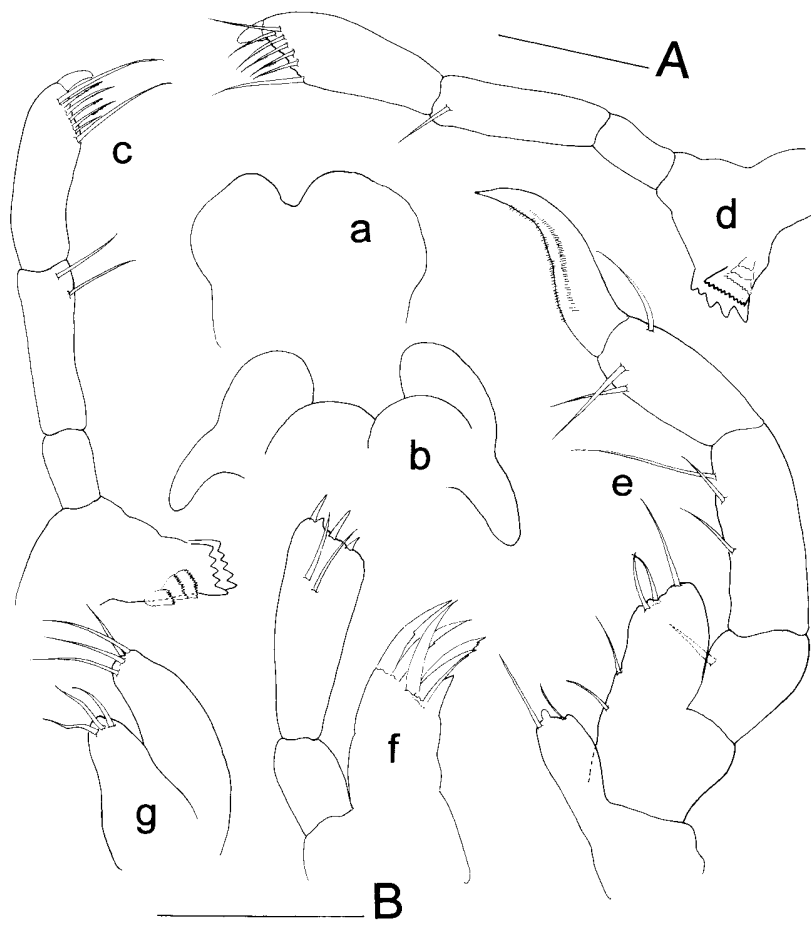

Fig. 8a-g Falotritella biscaynensis McCain, 1968. Male: a upper lip, b lower lip, c left mandible, d right mandible, e maxilliped, f maxilla $1, \mathbf{g}$ maxilla 2 . Scale bars $0.05 \mathrm{~mm}$. $A(\mathbf{a}-\mathbf{e}), B(\mathbf{f}, \mathbf{g})$

Gills on pereonites 3 and 4, elongate, length ca. 2 times width.

Antenna 1 ca. 1.6 times shorter than the body; article 3 of peduncle short, nearly $1 / 2$ of article 2 ; flagellum 8 -articulate.

Antenna 2 as long as peduncle of antenna 1; peduncular article 1 with an acute projection distally; swimming setae absent; flagellum 2-articulate.

Gnathopod 1 basis as long as ischium to carpus combined; propodus triangular carrying a pair of grasping spines proximally; grasping margin of dactylus and propodus not serrate.

Gnathopod 2 inserted in the anterior half of pereonite 2; basis as long as pereonite 2; propodus length ca. 2 times width; palm convex with a small proximal projection carrying a grasping spine and an acute projection medially.

Pereopods 3 and 4 subequal, very reduced, uni-articulate and carrying a pair of distal setae.

Pereopods 5-7 (missing in male "a" from Fig. 5, described from the other male) similar in feature increasing in length respectively, carrying a pair of small grasping spines situated on a round projection proximally.

Abdomen with a pair of lateral lobes and a single dorsal lobe carrying 2 plumose setae. Penes large, bilobed on distal end and situated medially.

Mouthparts: Upper lip with a pronounced excavation between lobes, smooth. Lower lip outer lobes smooth and small, but provided with a large projection. Maxilliped inner plate small and slender with 2 setae and 1 teeth 
apically; outer plate about 3 times larger than inner plate, carrying 3 apical setae; dactylus of palp slightly curved with grasping margin minutely serrated. Mandibles without molar process; incisor 5-toothed; lacinia mobilis 5-toothed in left mandible and divided into numerous teeth in right mandible; 3 accessory serrated plates in each mandible; palp 3-articulate, article 3 provided with a projection distally; setal formula 1-5-1. Maxilla 1 outer lobe with 5 stout apical teeth; distal article of the palp with 3 apical spines and 2 setae medially. Maxilla 2 outer lobe with 4 apical setae; inner lobe a little shorter than outer lobe, with 3 setae distally.

Mature female. Body length $6.3 \mathrm{~mm}$. Head with a dorsal acute projection. Pereonite 1 with a round projection; pereonites 2-5 provided with dorsal blunt setose instead of the rounded projections in male. Gnathopod 2 without the acute projection medially. Abdomen as in male.

Habitat

The red algae (McCain 1968), the green algae Avrainvillea and the sea-grass Thalassia (Gable and Lazo-Wasen 1987); between corals, through Cymodocea and Syringodium (present study).

Distribution

Type locality

Bear Cut, Key Biscayne, Florida, 2 m depth.

\section{Other records}

Bermuda; Soldier Key, Key Largo and Long Key, Florida; Tortugas; Barbuda; Pigem Island, Santa Lucia.

New record

Indian Ocean, Tanzania.

Remarks

McCain (1968) stated that this species was difficult to detect because of its small size and its usual covering by detritus. Specimens described by McCain (1968) were smaller (male $4 \mathrm{~mm}$, female $2.5 \mathrm{~mm}$ ) than those from Tanzania. Nevertheless, the present description is in agreement with the description of McCain (1968) based on specimens collected from Florida and Bermuda coasts. Gable and Lazo-Wasem (1987) reported five specimens of $F$. biscaynensis also from Bermuda. The present study is the second report of this species after the original description, and extends its known distribution to the Indian Ocean. Three species of Falotritella are known up until now; F. biscaynensis McCain, 1968, F. montoucheti Quitete, 1971 (Quitete 1971a) from Brazil and F. polynesica Müller, 1990 (Müller 1990) from Bora Bora and Morea, Society Islands.

\section{Family Caprellidae White, 1847}

Genus Paracaprella Mayer, 1890

Paracaprella tenuis Mayer, 1903

Mayer (1903) (Figs. 9, 10, 11, 12).

Paracaprella tenuis Mayer, 1903

Mayer (1903: p. 68, pl. 2, Figs. 34 and 35, pl. 7, Figs. 51 and 58); McCain and Steinberg (1970: p. 59); Laubitz (1972: pp. 67-68, pl. 18).

An extensive overview of all further synonymies is given by McCain and Steinberg (1970).

\section{Material examined}

Three males, six females from Bahary Beach at low tide, 25 December 1973; one female from Syringodium, 1 January 1974, one male from Fungia, 12 January 1974.

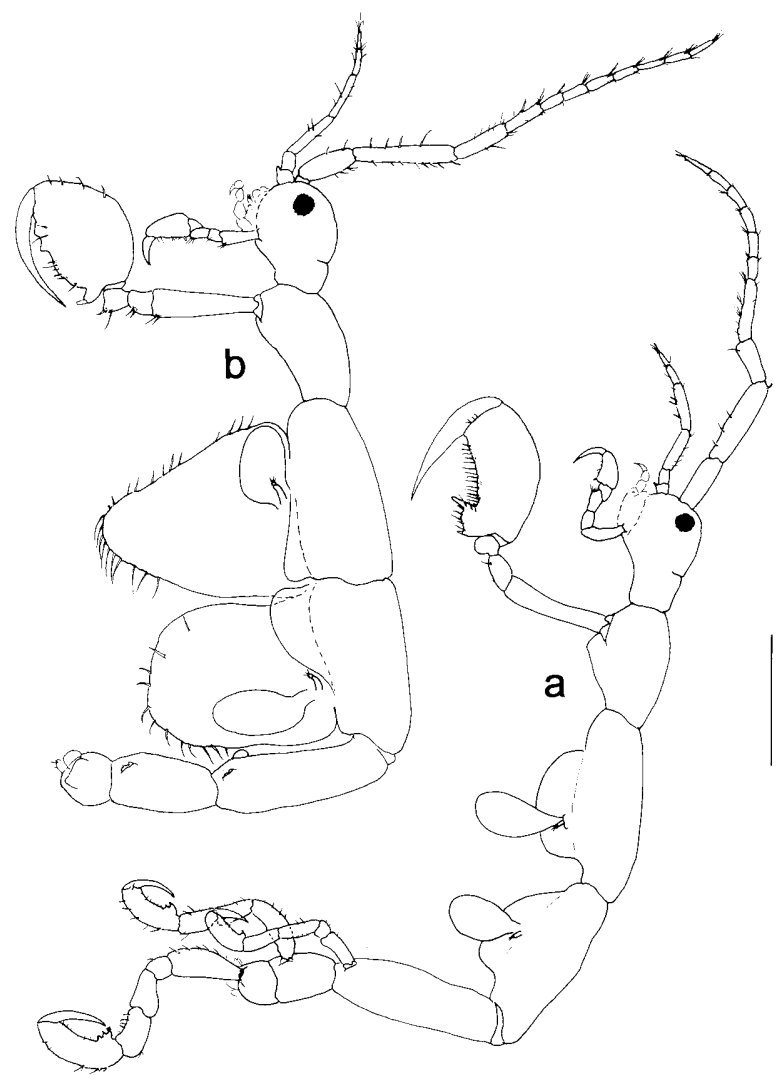

Fig. 9a, b Paracaprella tenuis Mayer, 1903. Lateral view. a Male, b female. Scale bar $0.05 \mathrm{~mm}$ 


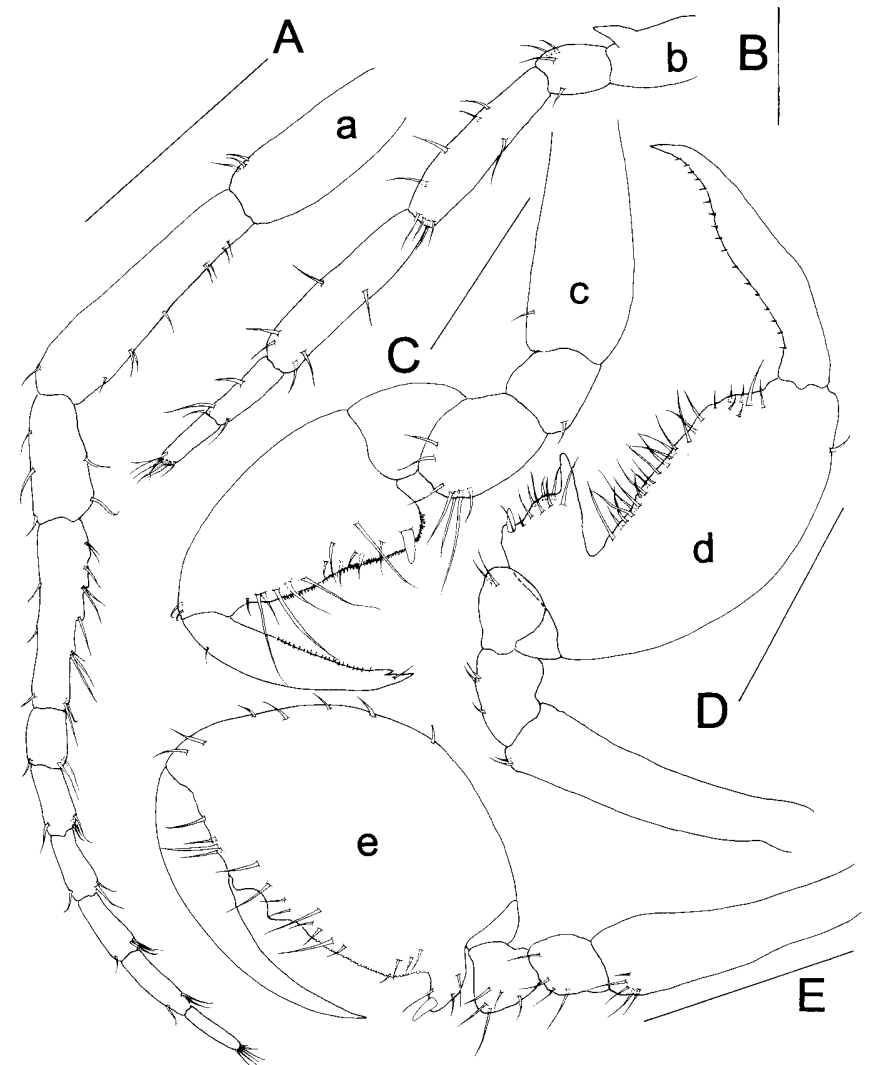

Fig. 10a-e Paracaprella tenuis Mayer, 1903. a-d Male: a antenna 1 , b antenna 2, $\mathbf{c}$ gnathopod $1, \mathbf{d}$ gnathopod 2. e Female gnathopod 2. Scale bars, A $0.3 \mathrm{~mm}(\mathbf{a}), B 0.1 \mathrm{~mm}(\mathbf{b}), C 0.1 \mathrm{~mm}(\mathbf{c})$, $D 0.3 \mathrm{~mm}(\mathbf{d}), E 0.3 \mathrm{~mm}(\mathbf{e})$
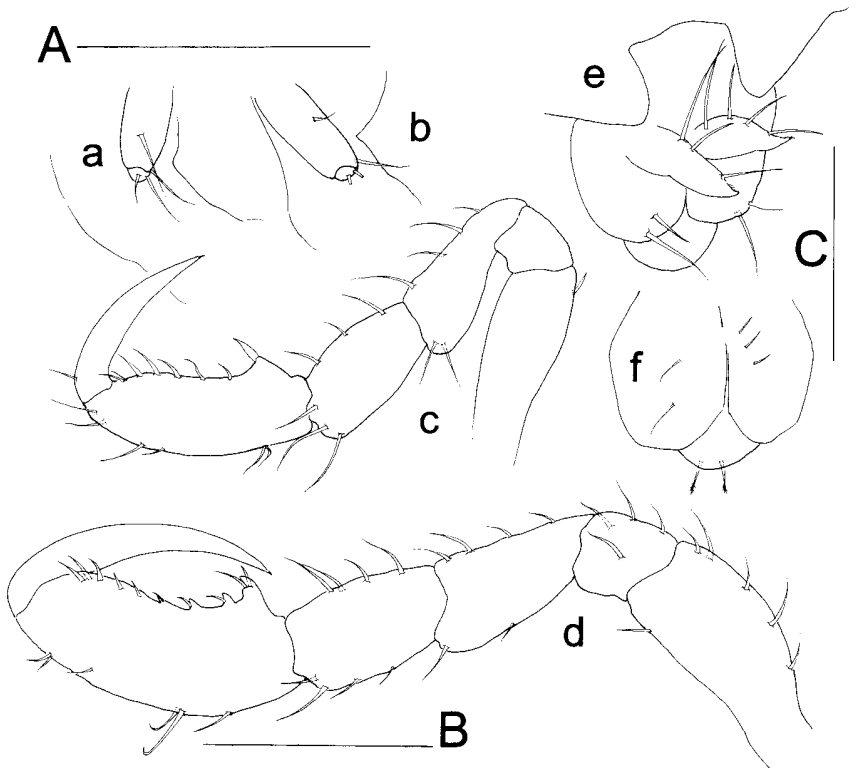

Fig. 11a-f Paracaprella tenuis Mayer, 1903. a-e Male: a pereopod 3, b pereopod 4, c pereopod 5, d pereopod 7, e abdomen. $\mathbf{f} \mathrm{Fe}-$ male abdomen. Scale bars, A $0.1 \mathrm{~mm}(\mathbf{a}, \mathbf{b}), B 0.2 \mathrm{~mm}(\mathbf{c}, \mathbf{d})$, $C 0.1 \mathrm{~mm}(\mathbf{e}, \mathbf{f})$

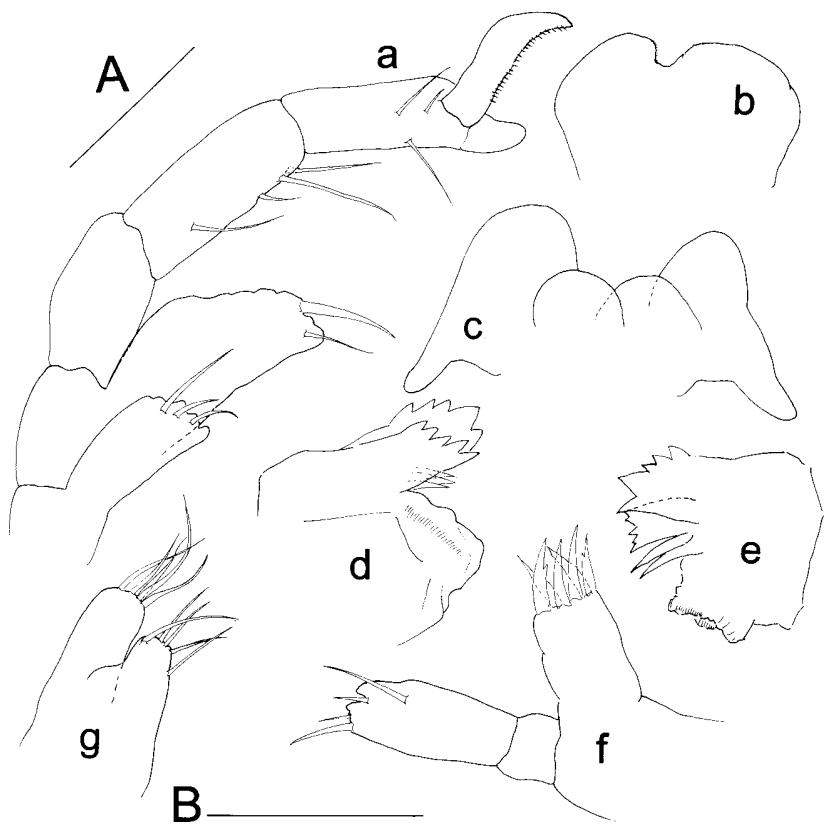

Fig. 12a-g Paracaprella tenuis Mayer, 1903. Male: a maxilliped, b upper lip, c lower lip, $\mathbf{d}$ left mandible, e right mandible, $\mathbf{f}$ maxilla $1, \mathbf{g}$ maxilla 2. Scale bars $0.05 \mathrm{~mm}$. $A(\mathbf{a}-\mathbf{c}), B(\mathbf{d}-\mathbf{g})$

\section{Description}

Mature male. Body length $6.7 \mathrm{~mm}$. Body dorsally smooth. Suture between head and pereonite 1 present; pleura on pereonites 3 and 4 well-developed; pereonites 3 and 4 subequal in length; pereonites 5 the longest. Gills on pereonites 2-4, oval, length ca. 2 times width.

Antenna 1 as long as the combined lengths of head and pereonite 1-3; peduncle not setose; flagellum with 7 articles.

Antenna 2 a little shorter than peduncle of antenna 1; swimming setae absent; peduncular article 1 with an acute projection distally; flagellum 2-articulate, both articles subequal in length.

Gnathopod 1 basis as long as ischium and carpus combined; propodus with a single proximal grasping spine; grasping margin of propodus and dactylus serrated.

Gnathopod 2 inserted in the anterior half of pereonite 2; basis as long as pereonite 2 but a little shorter than propodus; propodus length ca. 2 times width; propodus with a rectangular projection proximally, carrying a small proximal tooth; dactylus thickened medially.

Pereopods 3 and 4 subequal, 2-articulate; basal article with 1 setae; distal article ca. 5 times shorter than basal one, carrying 3 setae.

Pereopods 5-7 increasing in length in posterior direction; propodus of pereopod 5 carrying a single grasping spine proximally on palm; palm of pereopods $6-7$ with a pair of proximal grasping spine and several proximal knobs, each bearing a small spine.

Abdomen with a pair of uni-articulate appendages, a pair of lateral lobes and a single dorsal lobe; appendages 
acute apically, carrying 4 long setae. Penes short, situated laterally.

Mouthparts: Upper lip almost smooth, with a pronounced cleavage between lobes. Lower lip smooth; inner lobes relatively well-marked. Maxilliped inner plate lobulated apically, carrying 3 setae; outer plate with 2 apical setae; article 3 of the palp with a large process distally; terminal article with a row of setulae on grasping margin. Mandibles without palp; molar process present; incisor and lacinia mobilis 5-toothed; a row of 3 setae in the left mandible and 2 in the right one. Maxilla 1 outer lobe with 6 stout teeth apically; distal article of the palp with 3 apical spines and a setae medially. Maxilla 2 inner and outer lobe carrying 5 setae apically.

Mature female. Body length $7.2 \mathrm{~mm}$. Propodus of gnathopod 2 wider than in male, length ca. 1.3 times width; palm convex with a proximal projection carrying a grasping spine and 2 shorter projections distally; palm minutely serrated. Abdomen with a pair of lateral lobes and a single dorsal lobe carrying 2 plumose setae.

Habitat

Paracaprella tenuis had been previously collected from various red and brown algae, sea grass, sponges, hydroids, alcyonarians, bryozoans and from hydroids attached to the carapace of the spider crab Libinia (McCain 1968). Present specimens were collected from Syringodium and Fungia, and from corals.

Distribution

Type locality

Woods Hole, Massachusetts.

\section{Other localities}

Southwestern Gulf of St Lawerence, around Prince Edward Island; Pennellville, Maine; coast of North America from Cape Cod to Florida; Gulf of Mexico.

New record

Indian Ocean, Tanzania.

Remarks

Seven species have been described so far in the genus Paracaprella: P. alata Mayer, 1903; P. banardi McCain, 1967 (McCain 1967); P. crassa Mayer, 1903; P. digitimanus Quitete, 1971 (Quitete 1971b); P. insolita Arimoto, 1980 (Arimoto 1980); P. pusilla Mayer, 1890 and P. tenuis Mayer, 1903. Paracaprella tenuis is very similar to $P$. pusilla (Laubitz 1972). While $P$. tenuis has been recorded only from the West Atlantic coast, $P$. pusilla has been previously recorded from the West Atlantic coast and also from the African coasts (tropical West Africa, South Africa and Tanzania). Nevertheless, if we take into account the differences between the two species mentioned by McCain (1968) the present specimens belong to $P$. tenuis and not $P$. pusilla. According to McCain (1968), the males of $P$. pusilla differ markedly from those of $P$. tenuis by the large sharp-pointed projection on the antero-ventral margin of pereonite 2 , the proximal knob on the basis of gnathopod 2, and the presence of setae on the dactylus of gnathopod 2. Present specimens agree basically with those described by McCain (1968) and Laubitz (1970) for P. tenuis except for the absence of setae in the peduncle of antenna 1 and the complete absence of mandibular palp in all the specimens observed.

\section{Family Caprellidae White, 1847}

Genus Protella Dana, 1853

Protella similis Mayer, 1903

Mayer (1903) (Figs. 13, 14, 15, 16).

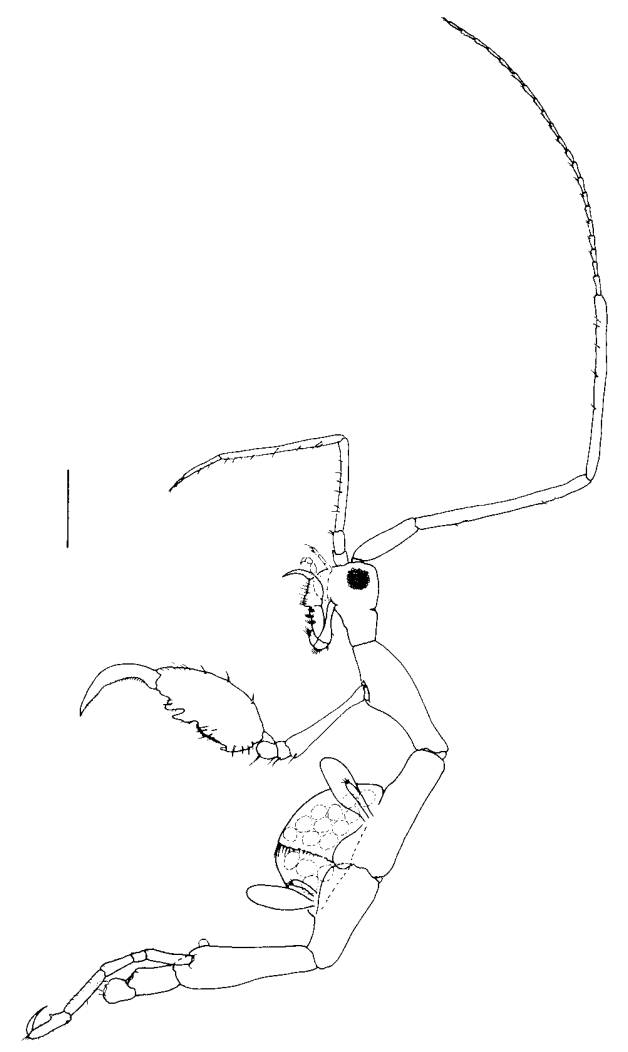

Fig. 13 Protella similis Mayer, 1903. Female, lateral view. Scale bar $1 \mathrm{~mm}$ 


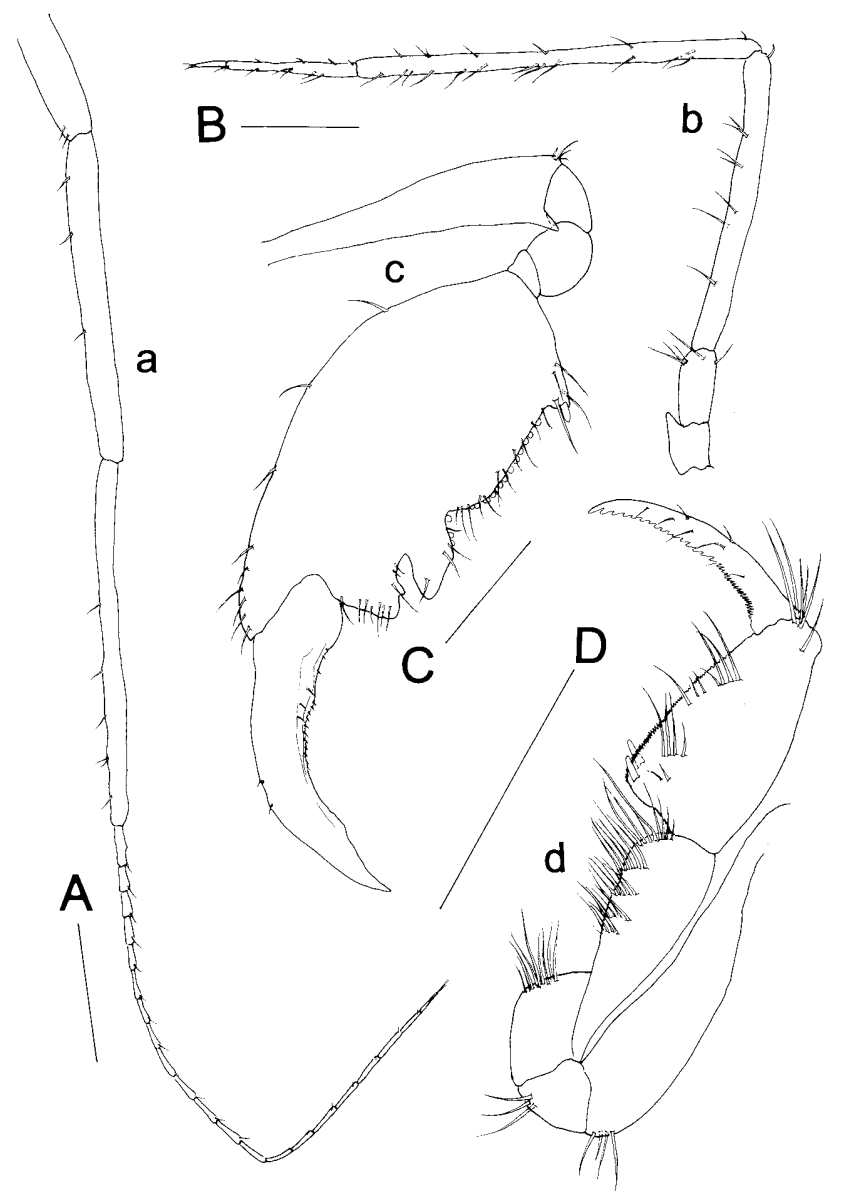

Fig. 14a-d Protella similis Mayer, 1903. Female: a antenna 1, b antenna 2, c gnathopod 2, d gnathopod 1. Scale bars, A $1 \mathrm{~mm}$ (a), $B-D 0.5 \mathrm{~mm}$. $B$ (b), $C$ (c), $D(\mathbf{d})$

Protella similis Mayer, 1903

Mayer (1903: pp. 34-35, pl. 1, Figs. 19-22, pl. 6, Figs. 41 and 42); McCain and Steinberg (1970: p. 70); Laubitz (1991: pp. 119, 121, Fig. 16).

\section{Material examined}

Two mature females from corals.

\section{Description}

Mature female. Body length $8.4 \mathrm{~mm}$. Body smooth. Eyes large, multifaceted and bulging laterally. Pereonites 2 and 3 subequal; pereonite 5 the longest. Gills on pereonites 3-4, elongate, length ca. 3 times width.

Antenna 1 ca. 1.2 times longer than the body; articles 2 and 3 of peduncle, subequal in length, scarcely setose; flagellum composed of 21 articles.

Antenna 2 ca. 2.5 times shorter than antenna 1 provided with short setae; peduncular article 1 with an acute

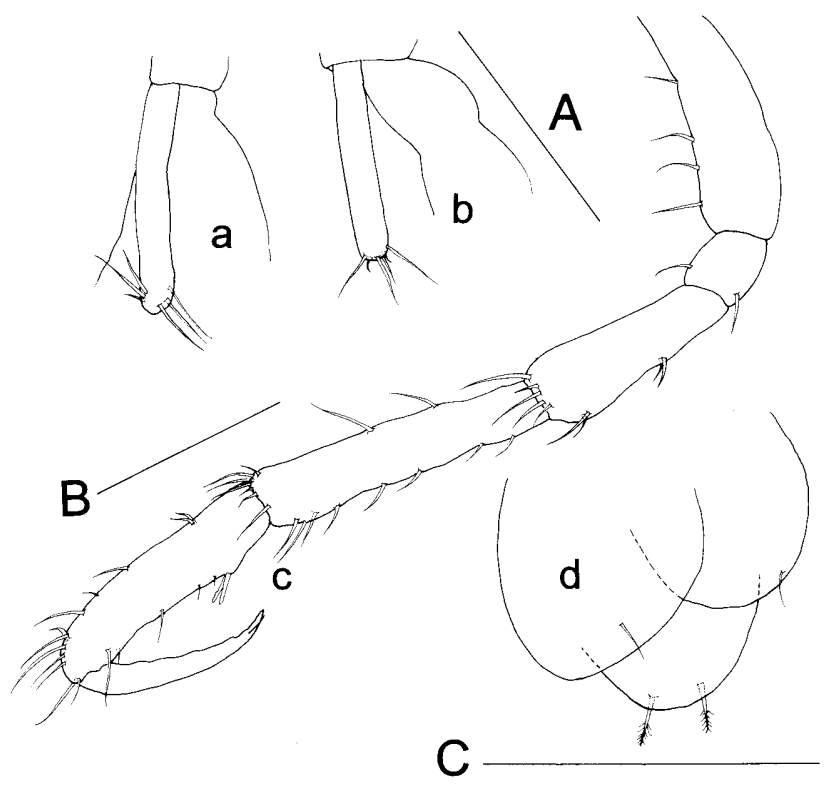

Fig. 15a-d Protella similis Mayer, 1903. Female: a pereopod 3, b pereopod 4, c pereopod 5, d abdomen. Scale bars, A $0.5 \mathrm{~mm}$ (a, b), $B 0.5 \mathrm{~mm}(\mathbf{c}), C: 0.2 \mathrm{~mm}(\mathbf{d})$

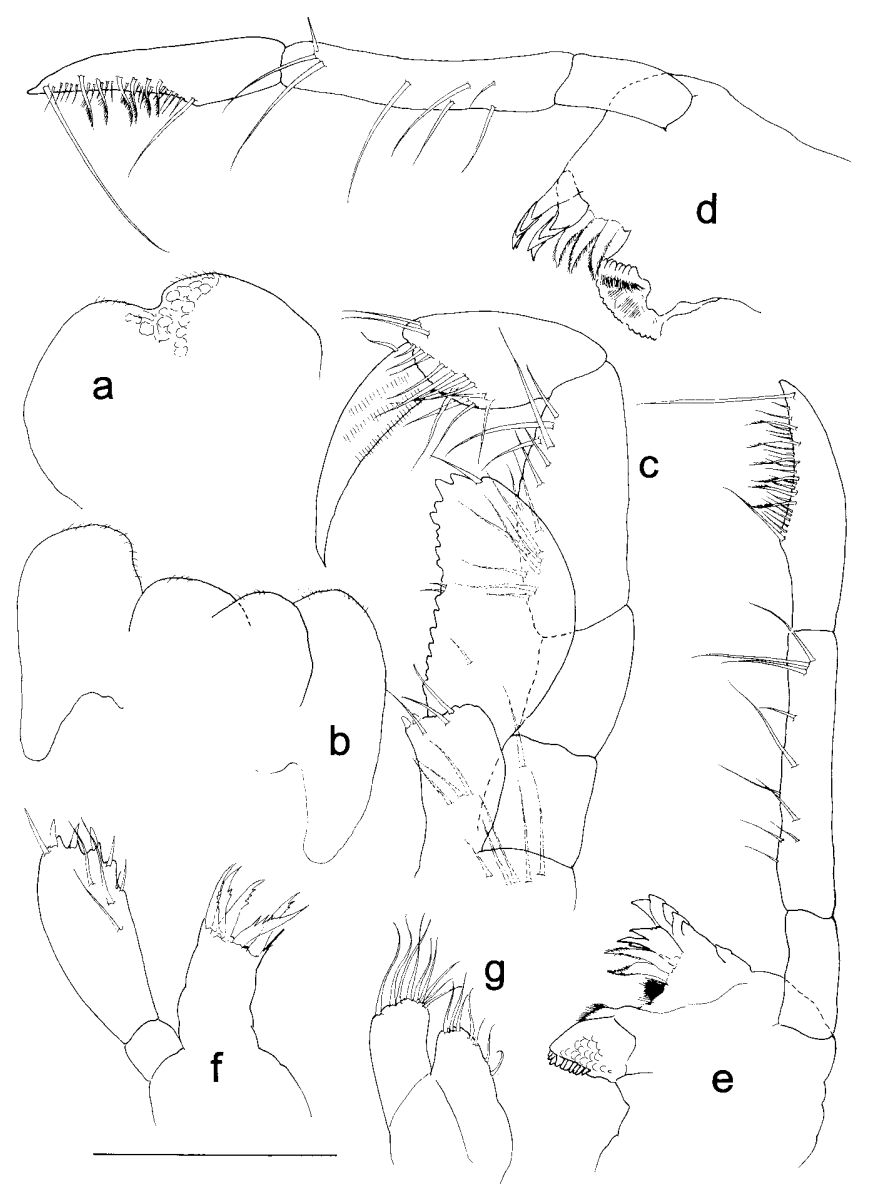

Fig. 16a-g Protella similis Mayer, 1903. Female: a upper lip, b lower lip, c maxilliped, $\mathbf{d}$ left mandible, e right mandible, f maxilla 1, g maxilla 2. Scale bar $0.2 \mathrm{~mm}$ 
projection distally; flagellum 2-articulate, proximal article ca. 3 times longer than distal one.

Gnathopod 1 basis a little shorter than ischium and carpus combined; carpus elongated, length ca. 3 times width with 5 parallel rows of setae ventrally; propodus as long as carpus, with a pair of proximal grasping spines; grasping margin of propodus and dactylus serrated.

Gnathopod 2 situated about 1/3 from the anterior end of the pereonite 2 ; basis ca. 0.8 times pereonite 2 in length, with anterodistal projection; propodus 1.2 times longer than basis, with a proximal grasping spine, a distal large projection followed by U-notch; palm bearing a row of "pegs" ["shiften" of Mayer (1903)].

Pereopods 3 and 4 with 1 article, carrying 6 setae on distal end; length ca. 5 times width, $1 / 2$ of the gill.

Pereopod 5 slender, very setose; propodus palm with 2 grasping spines.

Pereopods 6 and 7 missing in the two females collected.

Abdomen with a pair of lateral lobes and a single dorsal lobe which carries 2 plumose setae.

Mouthparts: Upper lip scaled distally, carrying short setae sparsely. Lower lip scarcely setose. Maxilliped inner plate carrying 3 setae and 2 small teeth; outer plate with an apical setae and jagged margin; articles 2 and 3 of the palp setose ventrally. Mandibles with molar welldeveloped; incisor 5-toothed; left lacinia mobilis 4-toothed and right one 2-toothed and serrated; palp 3 -articulate; article 2 with numerous setae; distal article with setal formula $1-x-y-1$ with $x$ being about 20 and $y=6$. Maxilla 1 outer lobe with 5 denticulate spiniform teeth; distal article of the palp with 4 distal spines and 4 setae medially. Maxilla 2 inner lobe oval, with 7 setae; outer lobe rectangular, larger than inner lobe, with 9 setae distally.

Habitat

The Tanzanian females were collected from corals.

\section{Distribution}

Type localities

Several locations in Indonesia and Thailand, 13-400 m in depth.

\section{Other localities}

Phillipines, $95 \mathrm{~m}$ in depth.

New records

Indian Ocean, west coast of Africa, Tanzania.
Remarks

This is the third report of Protella similis. Since its original description (Mayer 1903) this species was not found again until Laubitz (1991) studied the material collected by the expeditions to the western Pacific. Although Laubitz (1991) figured P. similis in detail, the description was not complete. Furthermore, since the new record is quite far from the previous localities, this species from Tanzania has been described and figured in detail for the purposes of comparison. The two studied females from Tanzania are very similar to the material from the western Pacific except for the 4-toothed left lacinia mobilis and the 5 denticulate teeth in the outer lobe of maxillae 1.

\section{Family Caprellidae White, 1847}

Genus Triprotella Arimoto, 1970

Triprotella amica Arimoto, 1970

Arimoto (1970) (Figs. 17, 18, 19).

Triprotella amica Arimoto, 1970

Arimoto (1970: pp. 71-73, Fig. 1).

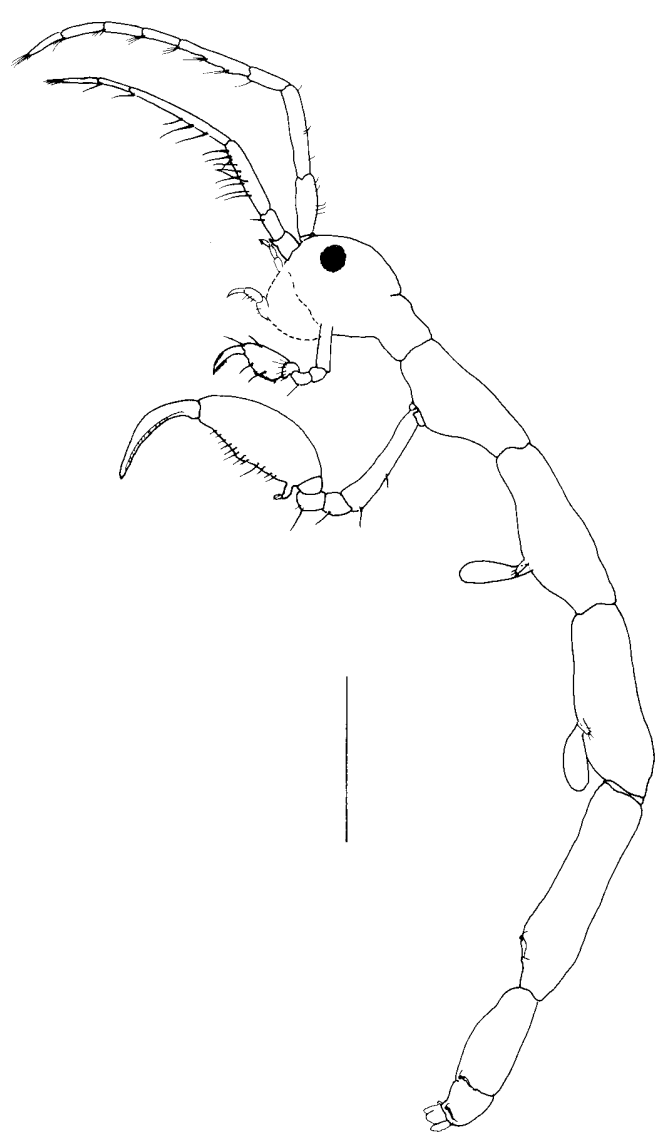

Fig. 17 Triprotella amica Arimoto, 1970. Male, lateral view. Scale bar $0.5 \mathrm{~mm}$ 


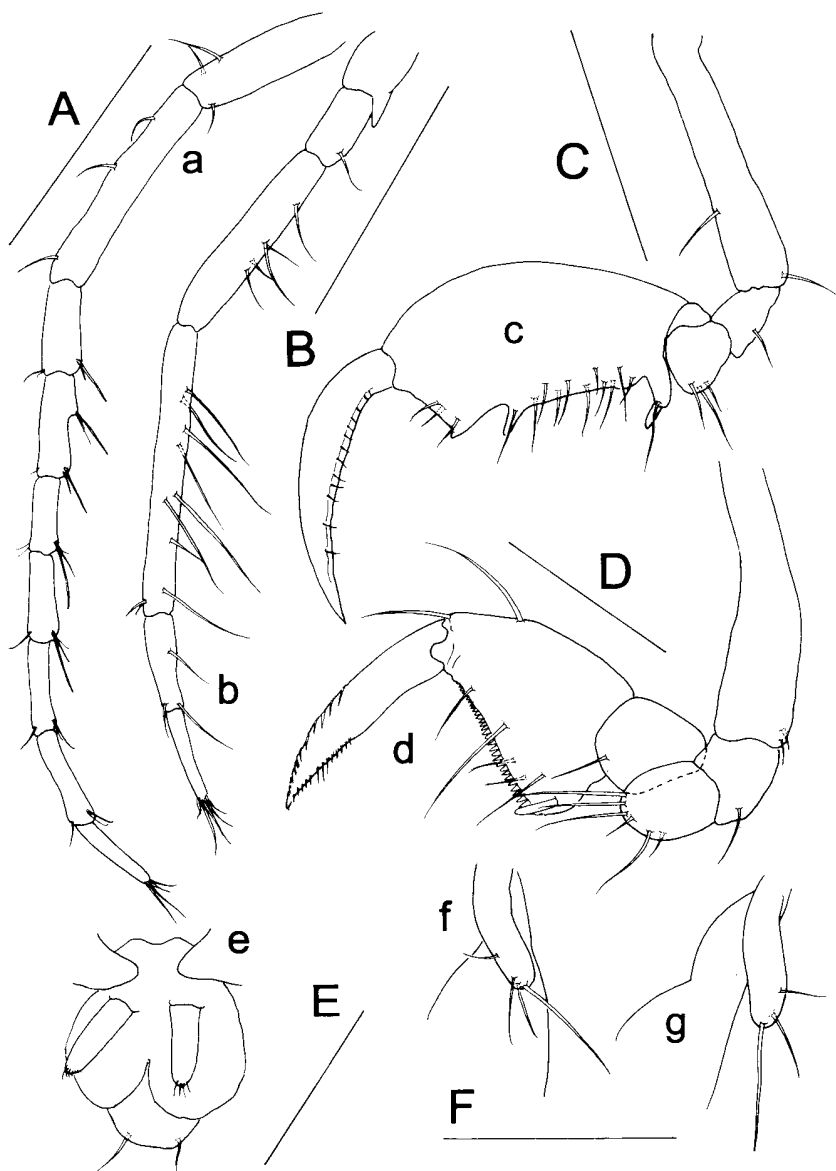

Fig. 18a-g Triprotella amica Arimoto, 1970. Male: a antenna 1, b antenna 2, c gnathopod 2, d gnathopod 1, e abdomen, $\mathbf{f}$ pereopod 3 , g pereopod 4. Scale bars, $A-C 0.3 \mathrm{~mm}$. $A$ (a), $B(\mathbf{b}), C$ (c). $D-F 0.1 \mathrm{~mm} . D(\mathbf{d}), E(\mathbf{e}), F(\mathbf{f}, \mathbf{g})$

\section{Material examined}

One male from Mbudya, sand, $5 \mathrm{~m}$ in depth, 21 December 1973.

\section{Description}

Mature male. Body length $6.3 \mathrm{~mm}$. Body smooth. Pereonites 3 and 4 subequal; pereonite 5 the longest. Gills on pereonites 3-4 elongated, length ca. 3.5 times width.

Antenna 1 slightly longer than head to pereonite 2 combined; peduncle scarcely setose; peduncular article 2 the longest, ca. 2 times longer than article 3; flagellum composed of 6 articles.

Antenna 2 a little shorter than antenna 1; peduncular article 1 with a small acute projection; flagellum with 2 articles, subequal in length.

Gnathopod 1 basis a little longer than ischium and carpus combined; propodus triangular, length ca. 1.2 times width proximally; palm serrated, with a proximal single grasping spine; dactylus with short spines dorsally and ventrally.

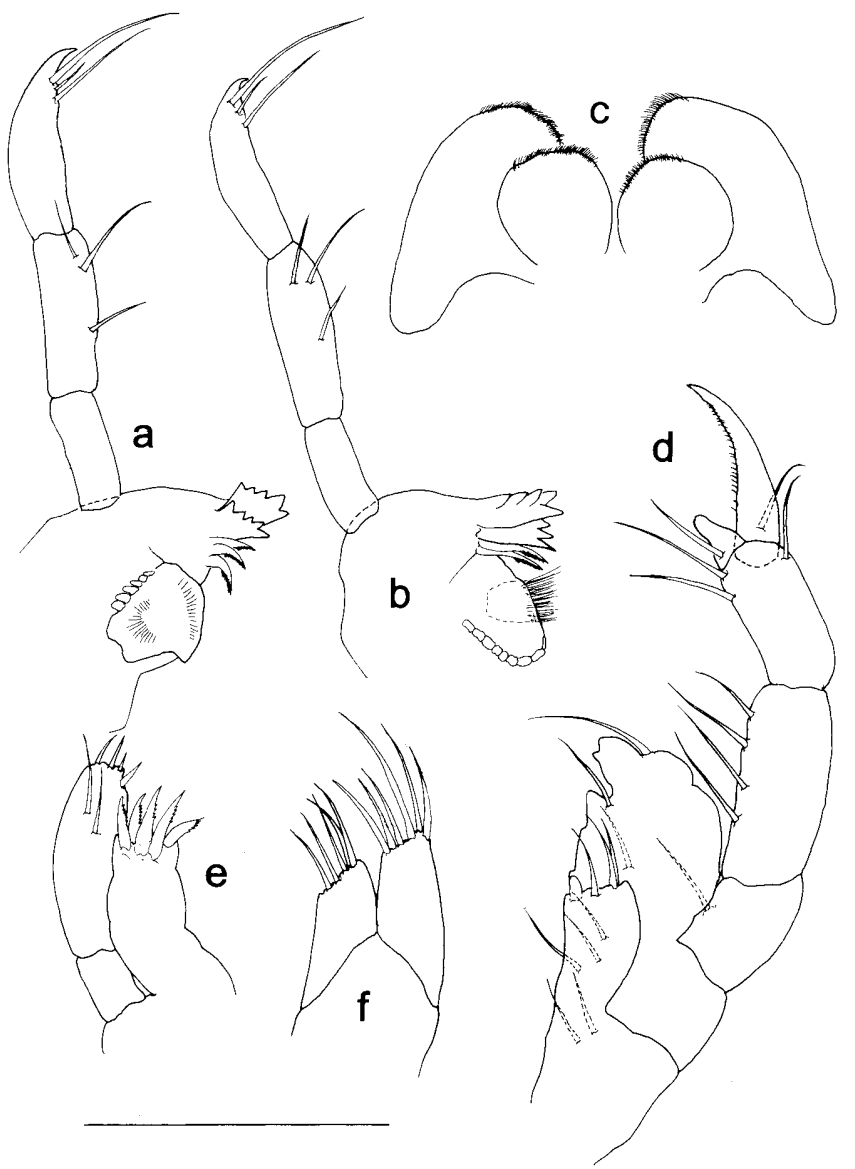

Fig. 19a-f Triprotella amica Arimoto, 1970. Male: a left mandible, b right mandible, c lower lip, d maxilliped, e maxilla 1, f maxilla 2. Scale bar $0.1 \mathrm{~mm}$

Gnathopod 2 inserted about 1/3 from the anterior end of pereonite 2; basis a little shorter than pereopod 2; carpus very reduced; propodus elongate, length ca. 2 times width; palm with a proximal slender projection carrying a grasping spine and a medial acute projection followed by Unotch; dactylus with a row of fine setae on inner margin.

Pereopods 3 and 4 subequal in length, uni-articulate, ca. 1/4 of gill length. Length ca. 3.5 times width; pereopod 3 carrying 3 spines on apical end and a single one medially; pereopod 4 with 2 apical spines and 1 medial spine.

Pereopods 5-7 missing. Nevertheless, observing the insertion we can state that they are not very reduced; pereopod 5 inserted posteriorly on the pereonite 5 .

Abdomen with a pair of appendages, a pair of lateral lobes and a single dorsal lobe which carries 2 simple setae. Appendages uni-articulate, carrying small setae apically; length ca. 4 times length. Penes short, situated laterally.

Mouthparts: Upper lip missing during the preparation in polyvinyl-lactophenol. Lower lip setose distally; inner lobes very well demarcated. Maxilliped inner plate rectangular, carrying 3 simple setae and a tooth apically; outer plate larger than inner one, provided with a jagged margin, carrying a setae on distal end and 2 setae medi- 
ally; article 3 of the palp with a well-developed process; dactylus slender with a proximal simple setae. Mandibles with strong molar process; incisor and lacinia mobilis 5-toothed; 3 pectinated setae in the left mandible and 2 in the right one; molar flake large and setose apically; palp 3-articulate; article 2 provided with 3 setae; article 3 acute apically with a setal formula 1-1-1. Maxillae 1 outer lobe with 5 serrated teeth; distal article of the palp with 4 spines distally and 2 setae medially. Maxillae 2 inner lobes with 5 setae; outer lobe, a little longer than inner lobe provided with 6 setae.

Habitat

The specimen described by Arimoto (1970) was obtained by dredging, at $90 \mathrm{~m}$ depth. The present specimen was collected from sand, $5 \mathrm{~m}$ in depth.

\section{Distribution}

Type locality

Arabian Sea off Oman $\left(19^{\circ} 54.7^{\prime} \mathrm{N}, 58^{\circ} 31.0^{\prime} \mathrm{E}\right)$.

New record

Tropical West Coast of Africa, Tanzania.

Remarks

Arimoto (1970) described the genus Triprotella based on a single specimen collected from the Arabian Sea, belonging to the type species Triprotella amica Arimoto, 1970. He stated that this species was rather similar to Metaprotella macrodactilos Stebbing, 1910 (Stebbing 1910) differing in the mandibular palp and the article 4 of the maxilliped palp. Nevertheless, he did not point out that in the genus Metaprotella, pereonites 6 and 7 are fused (e.g. Mayer 1903; Sivaprakasam 1977; Laubitz 1991) being the main difference between the genera $\mathrm{Me}$ taprotella and Triprotella.

The present specimen from Tanzanian waters resembles the genus Monoliropus Mayer, 1903. The three species in the genus, M. agilis Mayer, 1903, M. falcimanus Mayer, 1904 and M. tener Arimoto, 1968 (Arimoto 1968) show considerable overlap of very similar characters (Laubitz 1991). Nevertheless, the setal formula is $1-1-1$, the fact that pereopods 3 and 4 have one article and the morphology of the gnathopod 2 and abdomen indicate that the present specimen belongs to the genus Triprotella and not Monoliropus. However, we have found some differences between the present specimen and that described by Arimoto (1970). Eyes are reduced in Triprotella amica from the Arabian Sea whereas they are well developed in the specimen from Tanzania. In
T. amica from the Arabian Sea, article 3 of the maxilliped palp has no process and article 4 is blunt and rounded distally; the specimen from Tanzania has a well-developed process of article 3 of the maxilliped and article 4 is acute distally.

Acknowledgement I am very grateful to Dr Iorgu Petrescu for making possible the study of the Tanzanian caprellids and for his hospitality and kindness during my stay at the "Grigore Antipa" National Museum of Natural History, Bucharest.

\section{References}

Arimoto I (1968) A new caprellid (Amphipoda) Monoliropus tener n.sp. collected from Tateyama Bay. Bull Biogeogr Soc Jpn 24(8):59-61

Arimoto I (1970) Two new genera and three new species of caprellids (Amphipoda: Caprellidea) from the Arabian Sea. Bull Biogeogr Soc Jpn 24(11):71-78

Arimoto I (1980) Supplements to the Japanese caprellid fauna. I. Caprellids from the Korean Straits and adjacent waters. Publ Seto Mar Biol Lab 25:95-113

Gable MF, Lazo-Wasem EA (1987) The caprellids (Amphipoda: Caprellidea) of Bermuda: a survey of specimens collected from 1876-1987, including cave inhabitants, and the description of Deutella aspiducha, new species. Proc Biol Soc Wash 100:629-639

Guerra-García JM (2001) The Caprellidea (Crustacea: Amphipoda) collected by the expedition of "Grigore Antipa" National Museum of Natural History, from Tanzania, with the description of a new genus and two new species. Trav Mus Nat Hist Nat "Grigore Antipa" (in press)

Laubitz DR (1970) Studies on the Caprellidea (Crustacea: Amphipoda) of the American North Pacific. Nat Mus Can Publ Biol Oceanogr 1:1-89

Laubitz DR (1972) The Caprellidae (Crustacea, Amphipoda) of Atlantic and Arctic Canada. Nat Mus Can Publ Biol Oceanogr $4: 1-82$

Laubitz DR (1991) Crustacea Amphipoda Caprellidea: caprellids from the western Pacific (New Caledonia, Indonesia and the Philippines). In: Crosnier A (ed) Résultats des campagnes MUSOROSTOM, vol. 9. Mém Mus Natl Hist Nat (A) 152: $101-123$

Mayer P (1903) Die Caprelliden der Siboga-Expedition. Siboga Exped 34:1-160

McCain JC (1967) Paracaprella banardi, a new species of caprellid (Crustacea: Amphipoda) from the west coast of Panama. Proc Biol Soc Wash 80:219-222

McCain JC (1968) The Caprellidea (Crustacea: Amphipoda) of the Western North Atlantic. Bull U S Natl Mus 278(1-4):1-116

McCain JC, Steinberg JE (1970) Amphipoda. I. Caprellidea. I. Family Caprellidae. In: Gruner HE, Holthuis LB (eds) Crustaceorum catalogus $2: 1-78$

Müller HG (1990) New species and records of coral reef inhabiting Caprellidae from Bora Bora and Moorea, Society Islands (Crustacea: Amphipoda). Rev Suisse Zool 97(4):827-842

Quitete JMP (1971a) Fallotritella montoucheti, nova espécie de Caprellidae da Costa Brasileira (Crustacea: Amphipoda). Atas Soc Biol Rio de Janeiro 14(5-6):189-192

Quitete JMP (1971b) Paracaprella digitimanus, nova espécie de Caprellidae da Costa Brasileira (Crustacea: Amphipoda). Atas Soc Biol Rio de Janeiro 14(5-6):161-164

Sivaprakasam TE (1977) The skeleton shrimps (Amphipoda: Caprellidea) of the Tamil Nadu and Kerala Coasts. J Mar Biol Assoc India 19:78-96

Stebbing TRR (1910) General catalogue of South African Crustacea. Ann S Afr Mus 6(4):281-593

Sundara Raj MA (1927) Suborder Caprellidea (Laemodipoda). Bull Mad Govt Mus NS Nat Hist S 1:125-129 